\title{
The scholarly transition of female academics at the University of Granada (1975-1990)
}

\author{
ANA M. MUÑOZ-MUÑOZ \\ Women's Studies Institute, University of Granada (Spain)
}

\begin{abstract}
An attempt is made to shed light on part of Granada University's female academics' past in what was a critical period in Spain's history (1975-1982), referring of course to the political transition from dictatorship to democracy. The period studied is $1975-1990$, in which an analysis is made of a section of the teaching staff, using part of the female staff as the sample due to their being the most socially affected during this period. Firstly, a study is carried out on the teaching staff, both male and female, to verify the staff situation at the university using the gender indicator. Secondly, the female teachers' scholarly output is studied; due to the fact that areas of study are very varied, it has been considered appropriate to apply the study to monographs, scholarly publications articles and doctoral theses. Moreover, because the study intends to be as exhaustive as possible, various databases and catalogues have been consulted which collect the documental typology to be used in the analysis.
\end{abstract}

\section{Introduction}

This article wishes to show the process through which women came to become a part of research activity and how that process came about. The contribution to scholarly output by these women in the university context has not been paid attention to until very recently. Traditionally alienated from activities carried out by men, they have remained outside of the public space for a long time, that is to say, away from any recognition, of what is socially recognised and therefore from visibility. This small female presence in research activities begins to correct itself as women start to become a part of public life. To achieve this they have had to follow an arduous path, one whose very structure has been created by men, in order to reach representation within the results of university research. Through this research article the intention is to make a contribution towards increasing our presence in research, adding it to the scholarly output provided by women.

During the last quarter century that has just gone by, a series of political events took place in Spanish society, which made a peaceful transition possible, although not completely exempt from difficulties and conflicts of a different nature, from the

Received April 4, 2005

Address for correspondence:

ANA M. MUÑOZ-MUÑOZ

Women's Studies Institute, University of Granada, E-18071 Granada, Spain

E-mail: anamaria@ugr.es

$0138-9130 /$ US $\$ 20.00$

Copyright (C) 2005 Akadémiai Kiadó, Budapest

All rights reserved 
dictatorship imposed by the Franco regime to a democratic system. That period of our country's history has been named Spanish political transition (1975-1982), becoming one of the episodes to which we must inevitably recur in order to explain the rapid and profound changes experienced since then in all aspects of social, political, cultural, economic etc., life. It is true that these political events could not have unfolded in the way that they did if Spanish society had not been ready for the change. In this socialhistoric context a collective subject emerges, woman as a fundamental and historic key player in social change.

Women's participation in different areas of social life clearly shows the direction of these changes. But it was with the change over to a democratic system and the gradual political and legislative reforms that came into being, that access to university for women began to happen on a massive scale. The arrival of women in the university meant that they also started to take an active role in research. The result of such participation is embodied in the scholarly output produced by women forming part of university staff during that period of time. From a bibliographic analysis perspective, taking stock of that output and then studying it means helping to draw attention to women's contributions in the scholarly community.

\section{Bibliographic review}

The field of Information Science has concerned itself with the advance of science measuring scientist's output as a whole. Following through the articles published in the Scientometrics journal, up until the year 1988 there is no evidence of articles which study aspects related to the output of female scholars (CHAKRAVARTY, 1988). From this year onwards some articles sporadically appear in which the quantitative results not only define what event occurs and how it has been brought about, but also who participates in them, clarifying the reasons behind them.

In 1992 an article appears which carries out a study on the different types of output produced by scholarly men and women in Venezuela, using Lotka's law. This is the first article to make an analysis taking into account the author's gender and which examines the relevance of this type of distribution in a less developed country (LEMOINE, 1992).

The first piece of information available to us alluding to women's output contribution in the scholarly field is by PRICE (1973), when he refers to the studies carried out by Galton ${ }^{1}$ and by Linds R. Harmon. ${ }^{2}$ The argument is presented that science cannot grow more than eight per cent of the population, and that even so, such a

\footnotetext{
${ }^{1}$ Galton 1874 publishes a quality distribution among well-known scholars.

${ }^{2}$ Harmon (1960) studied people awarded Ph.D.s in the United States during 1958 using the AGCT intelligent test.
} 
figure is difficult to attain due to the fact that the percentage of scientists per one hundred doctors is on the decrease, pointing out that this limitation is due to the loss in female scholars. Since Price's reflection, which did not have a wide effect at the time, almost fifty years have passed during which the European Commission has published a report, pioneering in its class, which collects together the scholarly output in Science and Technology disaggregated according to gender $(100,000$ male/female inventors from six European Union countries - France, Germany, Italy, Spain, Sweden and the United Kingdom - as well as a sample of approximately 30,000 male/female authors of scholarly publications) (NALDI, F., 2002)

As far as scholarly output produced in Spanish universities and by the High Council for Scientific Research is concerned, several studies have been carried out ascertaining a considerable amount of growth in both institutions (See BORDONS, 1992a,b; MÉNDEZ, 1992; PeSTAÑA, 1992; CAMPANARIO, 1998), the second of these, is working through CINDOC to analyse its production, using gender indicators, within its eight technological areas during the 1996-2000 period. During 2003 a method for obtaining indicators disaggregated by gender has been developed, which was initially applied in the Agrarian Science field and at present is being extended to others (BORDONS, 2003; CINDOC, 2003). Apart from these projects, there is one in particular, produced by JIMÉNEZ (1997), which analyses scholarly output produced by the University of Granada during the time period 1975-1987. This research is based on the analysis of source references in journalistic publications using the Science Citation Index (SCI) as a basis, restricting itself to areas of study which adhere to specific Science disciplines, including areas belonging to the Science, Medical and Pharmacy Faculties. Just as in the case of the afore-mentioned studies, this one does not consider the gender variable either.

\begin{abstract}
Aims
Our study focuses on the scholarly output produced by female lecturers at the University of Granada from 1975 to 1990 . As has been mentioned above our study is restricted to the female group for the following reasons. The aim is to study scholarly output produced by female lecturers as a public expression of the social emergence of a group which up until then had remained confined to the private, domestic environment and which, within the time period already established, begins to join the public one and to have a voice of its own, taking on a fundamental role in deep social, political and cultural changes brought about in Spain during the last quarter of the twentieth century, a fact which continues to be true today although now from a different perspective, resulting from our country becoming part of the social and political dynamics happening in most of our neighbouring countries. The female group, seen as a historic subject for change, acquired greater representation during the democratic Transition
\end{abstract}


period in our country through women's movements fighting for a democratic state, this being the reason for our focus on the past period between 1975 and 1990

The University of Granada was chosen as the environment to qualify for the study of female lecturers' scholarly output for various reasons. In the first place, this university is of sufficient age and tradition, along with the corresponding prestige but also encrustation that these factors suppose, when it comes to innovation and change in relation to customs, values and attitudes in force at that historical time. However, for this same reason, it is in our judgement an accommodative institutional framework to study how and under what circumstances women's accession to university lecturing staff happens, by means analysing their research output. In a similar manner, the University of Granada is an institution which has great presence within the city where it is found and, in turn, the city greatly identifies itself with its University alike, and so the occurred changes and transformations in either of the two environments, city or university, influence and feed back to each other mutually. At the University of Granada just as in the rest of the country, the 1975-1990 period is marked by rapid changes in a brief span of time. By mentioning this our intention is to point out that a city such as Granada where the university institution has a specific influence, both in economic and social areas as in transmitting ideas and values, is an appropriate place to observe changes occurred during the Transition and whether or not these have any influence on the research activities of those female lecturers who became a part of the university during that period.

\section{Study material}

In order to obtain data relating to female lecturers' scholarly output during this period, as well as information about the teachers themselves, two types of information sources were used: administrative as far as identification of the teachers was concerned and bibliographic in order to locate all works making up their production.

Administrative sources, offering information through the Vice-Rectorate for Academic Planning at this university, includes three types of data: first and surnames of the female teachers hired at the university between 1975 and 1990 , there being $813^{3}$ women teachers included in this period, teaching areas to which they belong grouped into three broad study areas: Humanities and Social Sciences (HSS), ${ }^{4}$ Science and Technology (ST) and Medical and Life Sciences (MLS) and academic categories to

\footnotetext{
${ }^{3}$ Other sources such as the University Council and the National Statistics Institute record a much larger number of female teachers. The decision to use the date from the University of Granada's Academic ViceRector over the others is justified for being the only source providing teachers' full names.

${ }^{4}$ Law Sciences is included in the Social and Human Sciences.
} 
which the teachers belonged during the period studied; due to the great diversity of this final category as well as the changes suffered in their denomination, a decision was made to classify them in two groups: turned lecturers and associate professors.

Bibliographic sources used for the subsequent analysis of their research output are the following: on-line catalogues, bibliographic databases, Spanish indexes of national coverage, source reference and abstract journal indexes. With the aim of collecting the data concerning these teachers' scholarly output in the most comprehensive way possible, the references have been retrieved from seventeen national and international data bases, three of them of a general nature ${ }^{5}$ and the rest specialising in specific fields. ${ }^{6}$

The choice of bibliographic data bases used was made under the following criteria: the prestige of the institution that made it, the editor's experience, that it be trustworthy and well-known, that it included all the data necessary for the study, that it covered publications included within the time period to be studied, that it spanned a national and international geographic context, and finally the data bases specialisation in the different study areas.

For each of the major study areas: HSS, ST, and MLS, searches were made on different bibliographic databases with the aim to cover the whole time span of our study period. Furthermore, there are considerably fewer databases available on the market specialised in the Humanities and Social Sciences than in Technological and Medical Sciences. The latter have been greatly developed and diffused along with the rapid, parallel advances in technological innovation and applied medicine, which have had the advantage of their research results becoming known in a very short period of time and within an international context of dissemination, as opposed to a more local characteristic in social sciences studies and their dispersion of publications (See GLÄNZEL \& SCHOEPFLIN, 1999).

\section{Method}

Having consulted the sources, the next steps were to collect, select, organize and order the data in order to be able to apply the quantitative, descriptive analysis to them afterwards.

\footnotetext{
${ }^{5}$ Spanish National Bibliography (BNE), University of Granada Library Online Monograph Catalogue and Teseo (Database of doctoral thesis defended in Spain edited and published in Madrid by the Education and Culture Ministry's Data Processing Centre.

${ }^{6}$ Human and Social Sciences databases used: A\&HCI (Arts and Humanities Citation Index), Historical Abstracts, Spanish Human and Social Science Index (CSIC), MLA-International Bibliography (Modern Language Association of America International Bibliography of Books and Articles), PsycLIT (The American Psychological Association), SSCI (Social Science Citation Index). In science and technology, FSTA Current (Food Science and Technology Abstract), Spanish Science and Technology Index (CSIC), INSPEC, Math SCI, SCI (Science Citation Index). In medical and life science: CAB Abstracts Agriculture, Spanish Medical Index (CSIC), Medline.
} 
In order to analyse the development of scholarly output, the method used has been quantitative, descriptive analysis applied to the following aspects: female lecturers' accession into the University of Granada, academic status and scholarly output.

The accession process for female teachers into the University of Granada is analysed using the following indicators: number and percentage of teaching staff by years and gender, increase in teaching staff by years and gender, number and percentage of female teaching staff by years at the University of Granada and Spanish universities, number of female teachers by areas, yearly growth rate, which includes growth in female teachers and students at the University of Granada as percentages, percentage of women on the university teaching staff in HSS, in ST and in MLS, annual growth rate of both male and female teaching staff in HSS, ST and MLS and the percentage of women in different study areas.

Female teachers taking on these different categories and their moving around within the different study areas are analysed using the following indicators: Percentage of tenured lecturers and percentage of associate professors by gender in HSS, ST, and MLS.

In order to study their scholarly output an analysis was made of the following types of publications: monographs, articles in scholarly journals, doctoral theses. The second one of these types was chosen in order to cover output within the HSS; ST and MLS areas and the third one, the theses, because they are considered someone's first recognised research project in the academic world.

In the quantitative analysis of monographs, scholarly journal articles and theses the same work plan with some common directives was used:

a) Analysis of output by study areas.

In the analysis by study area and broad discipline areas a co-authored publication written by teachers belonging to different areas has been counted in each of the areas or broad areas.

b) A study of output by author.

A similar thing happens with the number of women teachers; although the number studied is 813 , there are 9 teachers who in a particular year during the study period change their discipline area; in this case they are counted twice. In the same way, this accounting of the number of publications and of female teachers will affect the number of female authors by broad discipline areas. For this reason, although in the results by broad areas the data are counted singly, in the totals it was decided to not count them in order to avoid double counting and explaining everything in the corresponding footnotes.

The frequency distribution shows us how many women authors publish a determined number of documents, providing us with the amount of documents normally published by the majority of women teachers. To this end, an analysis is made of the number of women authors with $n$ monographs to their name, $n$ being a value representing the possible number of publications per female teacher. 
When studying the number of female teachers publishing in each of the areas, an analysis was made firstly of data found in broad study areas and, afterwards, of those not found in the specific study areas. The following data were provided in both analyses: the number of women teachers from the study areas in which they publish, the number of women authors and the number of published documents in each of the areas. Using these data three types of indexes were calculated: authorship index, area productivity index and women author productivity index.

- The authorship index shows the degree of women teachers who publish a particular type of document within its area, and it is calculated in the following way: the number of women authors in that area during the 1975-1990 period divided by the number of women teachers in that area during the same period. With the aim of defining the authorship index results some values were predetermined, maximum value $=1$, in the case of all the area women teachers having published at least one type of document and the minimum value $=0$, if no female teacher in that area publishes. In any case, this minimum value will never be obtained due to the fact that the data included refers to areas in which a minimum of one type of document is published.

- The teacher productivity index shows the number of documents produced by a group of women teachers: The number of documents published in the study area during the 1975-1990 period divided by the total number of women teachers in the study area during the same period. The values established for this index are: minimum value\# 0 , because only areas where there is at least one document of any one female teacher during the whole period are included and the maximum value $=$ unlimited, as this will depend on the total amount of each type of document published in the study area, which, in theory, has no limit.

- The author productivity index shows the number of documents produced by the group of women authors who belong to that area: the number of published documents in the area during the 1975-1990 period divided by the number of women authors in that study area during the same period. The values adopted are: minimum value\#=1, because there is at least one document of any type per author within every area and for the whole period studied, and as a maximum value $=$ unlimited, because in the same way as with the authorship index, the maximum value has no theoretical limit.

- Below, the data disaggregated from the specific study areas are analysed. Concerning these results, three output levels are considered, depending on the number of publications per area during the whole period: high level of output, medium level of output and low level of output.

c) The output study by years allows us to see how women teachers' research activity evolved over time. In order to analyse the quantity of a particular type of publication published each year, a distribution was carried out for the number of publications in each of the sixteen years included in the study period (1975-1990). 
In the annual distribution study of production of a particular type of document produced by women teachers and by years. The annual output rate of a particular type of document by women authors has been formulated.

The annual distribution study of output of a particular type of document produced by female teachers in the broad areas of disciplines.

Due to the individual characteristics of each document, as well as the quantative analysis described above, it was also considered appropriate to apply a more specific analysis to some of the publications:

d) Roles carried out by women teachers as authors. This type of analysis was applied to monographic works, because it is in that context that authors take on different roles which are given two different categories that of creative author and that of noncreative author. Within the first category authors can be co-authors and collaborators and in the second they can be editors-compilers, director-coordinator, translator (all roles which are considered important) and prologuers and honorees (auxiliary roles). With this data the number and percentage of creative and non-creative authors was studied, and the number and percentage of monographs according to the authors' role.

e) Collaboration in publications. An analysis was made of the distribution of the number of articles by type of authorship in order to know in what proportion women teachers prefer to work as a team or individually. After that, the distribution of works signed by team work groups according to gender were looked at, and the distribution of the number of female/male authors making up the team.

By means of analysing the order of signatures, a study was made on the distribution of articles produced in collaboration, whose authors (male/female) do not appear in alphabetical order, in order to determine how often female teachers sign first when they work in team groups and to draw implications in this respect.

The evolution by years in the number of works in respect to the number of male/female authors that sign them, will reveal to us the tendencies to work together in collaboration groups, and in each of the broad discipline areas.

f) The impact factor of journals. In order to verify in which type of journals our women teachers publish, the Journal Citation Reports (JCR) has been consulted. For obvious reasons this analysis was carried out only on the scholarly journals articles.

g) Distribution in publishing institutions and publishing houses of monographic publications.

h) Doctoral theses supervision. In connection with doctoral theses, as well as the analysis common to all the types of documents, that is, the output by areas study, female teachers and years, an analysis is also made of their supervision and cosupervision taking into account the gender indicator. 


\section{Results}

In the distribution by gender among the broad discipline areas, a balance between male and female teaching staff is not seen. The broad discipline areas with a greater female presence are those of MLS and HSS, with less presence in ST. Moreover, in HSS and ST there are teaching areas where during this period there was no female presence, only $2.8 \%$ of a total of 71 areas and $34 \%$ of a total of 50 areas respectively. Both the increase in the number of female teachers as well as their accession into the teaching areas have been slow but steady. Female presence has increased since 1975 until 1990 in the different discipline areas but in few cases do they comprise $50 \%$ of the staff. If we refer to the feminisation process in the broad discipline areas as the continual accession of female teachers over the period and not as the place where there are more women teachers, then it the HSS area is the most feminised and not MLS. In both cases ST remains the "traditionally male" discipline.

Table 1. Proportion of women on the university teaching staff by broad discipline areas and years

\begin{tabular}{cccccccccc}
\hline & \multicolumn{2}{c}{ Human and Social Sciences } & \multicolumn{2}{c}{ Science and Technology } & \multicolumn{2}{c}{ Medical and Life Sciences } \\
& $\begin{array}{c}\text { Both } \\
\text { sexes }\end{array}$ & Females & \% Fem & $\begin{array}{c}\text { Both } \\
\text { sexes }\end{array}$ & Females & \% Fem & Both & Females & \% Fem \\
\hline 1975 & 47 & 7 & 14.9 & 49 & 10 & 20.4 & 48 & 10 & 20.8 \\
1976 & 62 & 11 & 17.7 & 59 & 11 & 18.6 & 55 & 11 & 20.0 \\
1977 & 71 & 12 & 16.9 & 62 & 10 & 16.2 & 59 & 12 & 20.4 \\
1978 & 91 & 16 & 17.6 & 74 & 15 & 20.3 & 69 & 12 & 17.4 \\
1979 & 103 & 19 & 18.5 & 81 & 15 & 18.5 & 82 & 19 & 23.2 \\
1980 & 115 & 20 & 17.4 & 88 & 18 & 20.5 & 94 & 22 & 23.4 \\
1981 & 147 & 30 & 20.4 & 103 & 20 & 19.4 & 104 & 25 & 24.1 \\
1982 & 152 & 34 & 22.4 & 117 & 22 & 18.8 & 118 & 30 & 25.4 \\
1983 & 196 & 38 & 19.4 & 163 & 27 & 16.6 & 152 & 40 & 26.3 \\
1984 & 238 & 52 & 21.8 & 211 & 34 & 16.1 & 179 & 47 & 26.3 \\
1985 & 356 & 109 & 30.6 & 253 & 42 & 16.6 & 228 & 64 & 28.1 \\
1986 & 427 & 124 & 29.1 & 312 & 47 & 15.1 & 279 & 82 & 29.4 \\
1987 & 590 & 175 & 29.6 & 426 & 76 & 17.8 & 411 & 135 & 32.8 \\
1988 & 768 & 237 & 30.9 & 527 & 102 & 19.4 & 472 & 156 & 33.1 \\
1989 & 1023 & 322 & 31.5 & 715 & 137 & 19.2 & 570 & 195 & 34.2 \\
1990 & 1253 & 386 & 30.8 & 893 & 180 & 20.2 & 659 & 218 & 33.1 \\
\hline
\end{tabular}


In terms of percentages, the number of female teachers with respect to the teaching staff as a whole oscillated between $8 \%$ and $16 \%$ in the $1975-1983$ period and after the University Reforms Law (LRU), ${ }^{7}$ in the 1984-1990 period, it increases considerably between $22 \%$ and $27 \%$. To a lesser extent, the number of non-tenured or contracted female teachers also increases oscillating between $25 \%$ and $32 \%$ in the $1975-1983$ period and as much as $29 \%$ and $37 \%$ in the $1984-1990$ period. Although there is still an imbalance between male and female teaching staff, it can be safe to say that both the female and male teachers' situation was advantaged by this politics, increasing the work situation for female teachers during these last years (Table 2).

\begin{tabular}{|c|c|c|c|c|c|c|c|c|c|c|}
\hline & \multicolumn{5}{|c|}{ Tenured } & \multicolumn{5}{|c|}{ Associate } \\
\hline & Total & Fem. & $\% \mathrm{~F}$ & Male & $\% \mathrm{M}$ & Total & Fem. & $\% \mathrm{~F}$ & Male & $\% \mathrm{M}$ \\
\hline 1975 & 72 & 6 & 8.3 & 66 & 91.7 & 72 & 21 & 29.2 & 51 & 70.8 \\
\hline 1976 & 84 & 9 & 10.7 & 75 & 89.3 & 92 & 24 & 26.1 & 68 & 73.9 \\
\hline 1977 & 92 & 9 & 9.8 & 83 & 90.2 & 100 & 25 & 25 & 75 & 75.0 \\
\hline 1978 & 124 & 14 & 11.3 & 110 & 88.7 & 110 & 29 & 26.4 & 81 & 73.6 \\
\hline 1979 & 145 & 19 & 13.1 & 126 & 86.9 & 121 & 34 & 28.1 & 87 & 71.9 \\
\hline 1980 & 161 & 21 & 13.1 & 140 & 86.9 & 136 & 39 & 28.7 & 97 & 71.3 \\
\hline 1981 & 210 & 34 & 16.2 & 176 & 83.8 & 144 & 41 & 28.5 & 103 & 71.5 \\
\hline 1982 & 230 & 36 & 15.6 & 194 & 84.4 & 157 & 50 & 31.8 & 107 & 68.1 \\
\hline 1983 & 341 & 49 & 14.4 & 292 & 85.6 & 170 & 56 & 32.9 & 114 & 67.1 \\
\hline 1984 & 454 & 72 & 15.8 & 382 & 84.2 & 173 & 61 & 35.3 & 112 & 64.7 \\
\hline 1985 & 673 & 154 & 22.9 & 519 & 77.1 & 163 & 61 & 37.4 & 102 & 62.6 \\
\hline 1986 & 860 & 197 & 22.9 & 663 & 77.1 & 158 & 56 & 35.4 & 102 & 64.6 \\
\hline 1987 & 1118 & 287 & 25.7 & 831 & 74.3 & 309 & 99 & 32.1 & 210 & 67.9 \\
\hline 1988 & 1258 & 334 & 26.5 & 924 & 73.5 & 509 & 161 & 31.6 & 348 & 68.4 \\
\hline 1989 & 1414 & 375 & 26.5 & 1039 & 73.5 & 895 & 279 & 31.2 & 616 & 68.8 \\
\hline 1990 & 1617 & 429 & 26.5 & 1188 & 73.5 & 1188 & 355 & 29.9 & 833 & 70.1 \\
\hline
\end{tabular}

In the discipline areas of ST and MLS the female presence with respect to contract categories of the teaching staff as a whole is higher, especially when they are Doctors. In the HSS area the female presence is higher in the non-tenured teachers not holding a Ph.D. It can also be confirmed that the point at which women come to belong to the highest category is very late on compared to men, whilst the latter join these ranks from the beginning of the period studied and in very large proportions, women join them

\footnotetext{
${ }^{7}$ Law passed by the Socialist Democratic Government in 1983. This law was an instrument of social change bringing about freedom, equality and social progress defending the principle of equality by eliminating the academic hierarchical structure. For example, concerning the selection and promotion processes it refers to abiding by the principles of merits, openness, and non-discrimination in the designation of all civil servant posts.
} 
later, and in different years depending on the discipline area. For example, the first tenured female lecturers in ST were in 1981, followed by MLS in 1983 and finally HSS in 1986. Perhaps it would be logical to suppose that the discipline areas with the most amount of women would have the most highest number of tenured female teachers, and yet this correlation is not so in some cases. Thus, in 1990 there were a total of 386 women in the HSS discipline area and only two of them were tenured, out of 180 women in ST there were only three and in MLS of a total of 218, seven were tenured, the highest (14.2\% of 49 tenured teachers). Another category where the female presence is noticeably late is in that of female tenured teachers who have not completed a thesis in the ST and MLS discipline areas, although this information is of little significance because it is due to the creation of new three-year University Colleges (Figure 1).

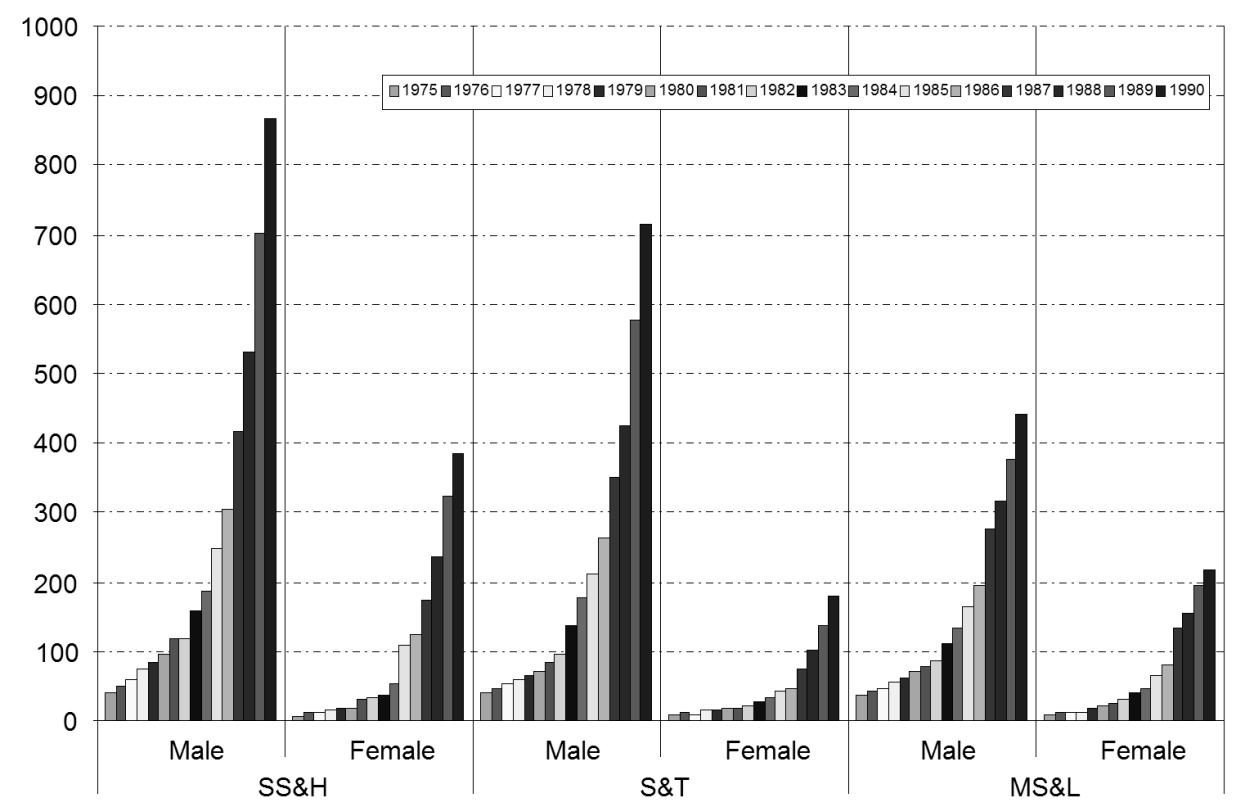

Figure 1. Teaching staff growth distribution by years and discipline areas

There is an even greater female presence in the university education system as far as the number of women teachers is concerned. Throughout the sixteen-year period studied, 1975-1990, it could be regarded that, generally speaking, there has been an increase in the amount of teaching staff at the University of Granada and especially in the female ones. This growth has been steady and can be seen in the accession of women teachers into new discipline areas where only males worked before. 
In what follows, we list which types of documents female teachers at the University of Granada prefer to use in order to report their research.

\section{Monographic publications}

A total of 253 monographic publications are published in $49.2 \%$ of the discipline areas. The highest level of output corresponds to the Library and Information Science area having 15 monographs to its name, this result being owed to the fact that it is a new area, created in 1983, and that it makes its field of knowledge known using manuals and study readers. Following it come the History of Art and Contemporary History areas, having 14 monographs each. The results of the monographic output study by broad discipline areas show that HSS has the greatest volume of output, with $82.6 \%$, compared to ST and MLS, having 8.9\% and 8.5\% each (Tables 3, 4 and 5).

In both HSS and ST all their female teachers publish in some of their areas, in the rest only a few do. In MLS not all women teachers publish. When the number of female teachers is higher in a discipline area, fewer of them publish, and vice versa.

Of the 446 female authors out of the female teachers at the University of Granada in the 1975-1990 period and who publish in the three types of documents analysed; 141 of them, almost one in three, have a published monograph to their name. The distribution of the number of female authors according to the number of their respective monographic publications reveals that many women teachers have written few books, whilst a small number of women teachers have written many.

As the authorship index shows, a little under a third of all women teachers at the University of Granada belonging to the areas where monographs are produced, have a published monograph. The total output rate for areas producing monographic publications during the whole period reaches an average of one monograph for every two teachers. However, if we take exclusive note of female authors, output goes up to almost two monographs per author. In absolute numbers, areas belonging to HSS are those which have most female teachers and authors, and therefore most published monographs. This is an entirely expected result, seeing as though the largest portion of discipline areas producing monographs belongs to HSS. Approximately one in three women teachers within the areas that produce monographs including HSS publish monographs during the period, whilst in MLS this level of monograph authorship descends to a little above one female author for every five female teachers, and for every 100 female teachers in the ST areas with monographic publications, only 16 have published monographs. A similar situation arises with respect to the level of monographic output of an area and the female authors' output level, since, in the latter case, within the HSS area each female author produces on average two monographs during the period, an average which is not reached in either ST or MLS (Table 6). 
A. M. MuÑOZ-MuÑOZ: Female academics at the University of Granada

Table 3. Publications. Female teachers and female authors distribution in Human and Social Science

\begin{tabular}{|c|c|c|c|c|c|c|c|c|c|c|c|c|}
\hline \multirow{2}{*}{$\begin{array}{l}\text { Discipline Areas in SS\&H } \\
\text { Arabic \& Islamic Studies }\end{array}$} & \multicolumn{2}{|c|}{ Fem. Teach. } & \multicolumn{2}{|c|}{ Fem. Author } & \multicolumn{2}{|c|}{ Books } & \multicolumn{2}{|c|}{ Articles } & \multicolumn{2}{|c|}{ Thesis } & \multicolumn{2}{|c|}{ Total } \\
\hline & 11 & $2.7 \%$ & 11 & $5.9 \%$ & 12 & $5.6 \%$ & 46 & $12.4 \%$ & 8 & $7.1 \%$ & 66 & $9.4 \%$ \\
\hline Library and Information Science & 10 & $2.4 \%$ & 8 & $4.3 \%$ & 15 & $7.0 \%$ & 35 & $9.4 \%$ & 2 & $1.8 \%$ & 52 & $7.4 \%$ \\
\hline English Studies & 38 & $9.3 \%$ & 14 & $7.5 \%$ & 3 & $1.4 \%$ & 35 & $9.4 \%$ & 7 & $6.2 \%$ & 45 & $6.4 \%$ \\
\hline Contemporary History & 3 & $0.7 \%$ & 1 & $0.5 \%$ & 14 & $6.5 \%$ & 24 & $6.5 \%$ & 1 & $0.9 \%$ & 39 & $5.6 \%$ \\
\hline Prehistory & 5 & $1.2 \%$ & 5 & $2.7 \%$ & 5 & $2.3 \%$ & 31 & $8.4 \%$ & 2 & $1.8 \%$ & 38 & $5.4 \%$ \\
\hline Hebrew \& Aramean Studies & 4 & $1.0 \%$ & 4 & $2.1 \%$ & 13 & $6.1 \%$ & 15 & $4.0 \%$ & 3 & $2.6 \%$ & 31 & $4.4 \%$ \\
\hline Modern History & 6 & $1.5 \%$ & 5 & $2.7 \%$ & 13 & $6.1 \%$ & 13 & $3.5 \%$ & 5 & $4.4 \%$ & 31 & $4.4 \%$ \\
\hline Mathematics Teach. Methodology & 8 & $2.0 \%$ & 7 & $3.8 \%$ & 13 & $6.1 \%$ & 16 & $4.3 \%$ & 1 & $0.9 \%$ & 30 & $4.3 \%$ \\
\hline Ancient History & 4 & $1.0 \%$ & 3 & $1.6 \%$ & 8 & $3.7 \%$ & 16 & $4.3 \%$ & 3 & $2.6 \%$ & 27 & $3.9 \%$ \\
\hline Spanish Studies & 15 & $3.6 \%$ & 10 & $5.4 \%$ & 11 & $5.1 \%$ & 9 & $2.4 \%$ & 6 & $5.3 \%$ & 26 & $3.7 \%$ \\
\hline Personality,Psych.Eval.\&Treatment & & $1.5 \%$ & 6 & $3.3 \%$ & 6 & $2.8 \%$ & 13 & $3.5 \%$ & 5 & $4.4 \%$ & 24 & $3.4 \%$ \\
\hline Penal Law & 8 & $2.0 \%$ & 4 & $2.1 \%$ & 9 & $4.2 \%$ & 11 & $3.0 \%$ & 3 & $2.6 \%$ & 23 & $3.3 \%$ \\
\hline History of Art & 11 & $2.7 \%$ & 8 & $4.3 \%$ & 14 & $6.5 \%$ & 2 & $0.5 \%$ & 6 & $5.3 \%$ & 22 & $3.1 \%$ \\
\hline Theory of Literature & 5 & $1.2 \%$ & 3 & $1.6 \%$ & 5 & $2.3 \%$ & 12 & $3.2 \%$ & 3 & $2.6 \%$ & 20 & $2.9 \%$ \\
\hline History Science and Techniques & 6 & $1.5 \%$ & 6 & $3.3 \%$ & 9 & $4.2 \%$ & 5 & $1.3 \%$ & 4 & $3.5 \%$ & 18 & $2.6 \%$ \\
\hline Latin Studies & 7 & $1.7 \%$ & 6 & $3.3 \%$ & 12 & $5.6 \%$ & & & 6 & $5.3 \%$ & 18 & $2.6 \%$ \\
\hline Developmental\&Education.Psych. & 9 & $2.2 \%$ & 5 & $2.7 \%$ & 6 & $2.8 \%$ & 6 & $1.6 \%$ & 1 & $0.9 \%$ & 13 & $1.9 \%$ \\
\hline Education Theory \& History & 4 & $1.0 \%$ & 1 & $0.5 \%$ & 2 & $0.9 \%$ & 8 & $2.2 \%$ & 1 & $0.9 \%$ & 11 & $1.6 \%$ \\
\hline Psychobiology & 6 & $1.5 \%$ & 5 & $2.7 \%$ & & & 8 & $2.2 \%$ & 3 & $2.6 \%$ & 11 & $1.6 \%$ \\
\hline Medieval History & 6 & $1.5 \%$ & 4 & $2.1 \%$ & 5 & $2.3 \%$ & 1 & $0.3 \%$ & 4 & $3.5 \%$ & 10 & $1.4 \%$ \\
\hline French Studies & 20 & $4.9 \%$ & 7 & $3.7 \%$ & 2 & $0.9 \%$ & 4 & $1.1 \%$ & 3 & $2.6 \%$ & 9 & $1.3 \%$ \\
\hline Moral \& Political Law Philosophy & 1 & $0.2 \%$ & 1 & $0.5 \%$ & & & 8 & $2.2 \%$ & 1 & $0.9 \%$ & 9 & $1.3 \%$ \\
\hline Prosecution Law & 5 & $1.2 \%$ & 4 & $2.1 \%$ & 4 & $1.9 \%$ & 2 & $0.5 \%$ & 3 & $2.6 \%$ & 9 & $1.3 \%$ \\
\hline Lang. \& Lit. Teach. Methodology & 17 & $4.1 \%$ & 4 & $2.1 \%$ & 2 & $0.9 \%$ & 6 & $1.6 \%$ & & & 8 & $1.1 \%$ \\
\hline Research Meth.Educational Diagno & 4 & $1.0 \%$ & 4 & $2.1 \%$ & 4 & $1.9 \%$ & 3 & $0.8 \%$ & 1 & $0.9 \%$ & 8 & $1.1 \%$ \\
\hline Teaching Method.\&School Manage & 10 & $2.4 \%$ & 4 & $2.1 \%$ & 4 & $1.9 \%$ & 2 & $0.5 \%$ & 2 & $1.8 \%$ & 8 & $1.1 \%$ \\
\hline American History & 1 & $0.2 \%$ & 1 & $0.5 \%$ & & & 6 & $1.6 \%$ & 1 & $0.9 \%$ & 7 & $1.0 \%$ \\
\hline Basic Psychology & 3 & $0.7 \%$ & 3 & $1.6 \%$ & & & 6 & $1.6 \%$ & 1 & $0.9 \%$ & 7 & $1.0 \%$ \\
\hline Translation Applied Linguistics & 4 & $1.0 \%$ & 1 & $0.5 \%$ & & & 7 & $1.9 \%$ & & & 7 & $1.0 \%$ \\
\hline German Studies & 9 & $2.2 \%$ & 4 & $2.1 \%$ & 1 & $0.5 \%$ & 5 & $1.3 \%$ & & & 6 & $0.8 \%$ \\
\hline Italian Studies & 5 & $1.2 \%$ & 3 & $1.6 \%$ & 3 & $1.4 \%$ & & & 3 & $2.6 \%$ & 6 & $0.8 \%$ \\
\hline Philosophy & 3 & $0.7 \%$ & 1 & $0.5 \%$ & 2 & $0.9 \%$ & 3 & $0.8 \%$ & 1 & $0.9 \%$ & 6 & $0.8 \%$ \\
\hline Archeology & 2 & $0.5 \%$ & 2 & $1.1 \%$ & 1 & $0.5 \%$ & 2 & $0.5 \%$ & 2 & $1.8 \%$ & 5 & $0.7 \%$ \\
\hline Romance Studies & 1 & $0.2 \%$ & 1 & $0.5 \%$ & 3 & $1.4 \%$ & 2 & $0.5 \%$ & & & 5 & $0.7 \%$ \\
\hline Social Sciences Teach. Method. & 7 & $1.7 \%$ & 1 & $0.5 \%$ & 4 & $1.9 \%$ & & & 1 & $0.9 \%$ & 5 & $0.7 \%$ \\
\hline Civil Law & 11 & $2.7 \%$ & 2 & $1.1 \%$ & & & 2 & $0.5 \%$ & 2 & $1.8 \%$ & 4 & $0.6 \%$ \\
\hline Galician \& Portuguese Studies & 2 & $0.5 \%$ & 2 & $1.1 \%$ & 1 & $0.5 \%$ & 2 & $0.5 \%$ & 1 & $0.9 \%$ & 4 & $0.6 \%$ \\
\hline Musical Expression Teach.Method. & 12 & $2.9 \%$ & 2 & $1.1 \%$ & 1 & $0.5 \%$ & 2 & $0.5 \%$ & & & 3 & $0.4 \%$ \\
\hline Behavioural Science Methodology & 2 & $0.5 \%$ & 1 & $0.5 \%$ & & & 1 & $0.3 \%$ & 1 & $0.9 \%$ & 2 & $0.3 \%$ \\
\hline Ecclesiastic State Law & 3 & $0.7 \%$ & 2 & $1.1 \%$ & & & & & 2 & $1.8 \%$ & 2 & $0.3 \%$ \\
\hline Financial \& Income Tax Law & 6 & $1.5 \%$ & 1 & $0.5 \%$ & 1 & $0.5 \%$ & & & 1 & $0.9 \%$ & 2 & $0.3 \%$ \\
\hline Greek Studies & 3 & $0.7 \%$ & 2 & $1.1 \%$ & & & & & 2 & $1.8 \%$ & 2 & $0.3 \%$ \\
\hline Public International Law & 5 & $1.2 \%$ & 2 & $1.1 \%$ & 1 & $0.5 \%$ & & & 1 & $0.9 \%$ & 2 & $0.3 \%$ \\
\hline Social Psychology & 4 & $1.0 \%$ & 1 & $0.5 \%$ & & & 1 & $0.3 \%$ & 1 & $0.9 \%$ & 2 & $0.3 \%$ \\
\hline Social Security Work Law & 9 & $2.4 \%$ & 1 & $0.5 \%$ & 1 & $0.5 \%$ & & & 1 & $0.9 \%$ & 2 & $0.3 \%$ \\
\hline Sociology & 8 & $2.0 \%$ & 1 & $0.5 \%$ & 1 & $0.5 \%$ & & & 1 & $0.9 \%$ & 2 & $0.3 \%$ \\
\hline Artistic Expression Teaching Metho & 6 & $1.5 \%$ & 1 & $0.5 \%$ & 1 & $0.5 \%$ & & & & & 1 & $0.1 \%$ \\
\hline Catalan Studies & 1 & $0.2 \%$ & 1 & $0.5 \%$ & & & & & 1 & $0.9 \%$ & 1 & $0.1 \%$ \\
\hline Constitutional Law & 1 & $0.2 \%$ & 1 & $0.5 \%$ & & & & & 1 & $0.9 \%$ & 1 & $0.1 \%$ \\
\hline Experimental Science Teach. Meth & & $0.7 \%$ & 1 & $0.5 \%$ & & & & & 1 & $0.9 \%$ & 1 & $0.1 \%$ \\
\hline Financial \& Accountancy Economic & & $2.2 \%$ & 1 & $0.5 \%$ & & & 1 & $0.3 \%$ & & & 1 & $0.1 \%$ \\
\hline Music. & 3 & $0.7 \%$ & 1 & $0.5 \%$ & 1 & $0.5 \%$ & & & & & 1 & $0.1 \%$ \\
\hline Political and Administrative Science & 5 & $1.2 \%$ & 1 & $0.5 \%$ & & & & & 1 & $0.9 \%$ & 1 & $0.1 \%$ \\
\hline Private International Law & 1 & $0.2 \%$ & 1 & $0.5 \%$ & & & & & 1 & $0.9 \%$ & 1 & $0.1 \%$ \\
\hline Roman Law & 3 & $0.7 \%$ & 1 & $0.5 \%$ & & & & & 1 & $0.9 \%$ & 1 & $0.1 \%$ \\
\hline Social Work \& Social Services & 2 & $0.5 \%$ & 1 & $0.5 \%$ & 1 & $0.5 \%$ & & & & & 1 & $0.1 \%$ \\
\hline Technical Drawing & 5 & $1.2 \%$ & 2 & $1.1 \%$ & & & & & 1 & $0.9 \%$ & 1 & $0.1 \%$ \\
\hline Administative Law & 1 & $0.2 \%$ & & & & & & & & & & \\
\hline Applied Economics & 8 & $2.0 \%$ & & & & & & & & & & \\
\hline Business Organisation & 3 & $0.7 \%$ & & & & & & & & & & \\
\hline History \& Institutional Economics & 3 & $0.7 \%$ & & & & & & & & & & \\
\hline History of Institutional Law & 4 & $1.0 \%$ & & & & & & & & & & \\
\hline Market Research and Commercialis & & $0.2 \%$ & & & & & & & & & & \\
\hline Marketing Law & 2 & $0.5 \%$ & & & & & & & & & & \\
\hline Painting & 5 & $1.2 \%$ & & & & & & & & & & \\
\hline Performing Arts Teac & 2 & $0.5 \%$ & & & & & & & & & & \\
\hline Physical \& Sport Education & 5 & $1.2 \%$ & & & & & & & & & & \\
\hline Sculpture & 6 & $1.5 \%$ & & & & & & & & & & \\
\hline Teacher Training Institute & 2 & $0.5 \%$ & & $2.1 \%$ & & & & & & & & \\
\hline
\end{tabular}


A. M. MuÑOZ-MuÑOZ: Female academics at the University of Granada

Table 4. Publications. Female teachers and authors distribution in Science and Technology

\begin{tabular}{|c|c|c|c|c|c|c|c|c|c|c|c|}
\hline \multirow{2}{*}{$\begin{array}{l}\text { Discipline Areas in S\&T } \\
\text { Chemical Engineering }\end{array}$} & \multicolumn{2}{|c|}{ Fem. Teach. } & \multicolumn{2}{|c|}{ Fem. Author } & \multicolumn{2}{|c|}{ Books } & \multicolumn{2}{|c|}{ Articles } & \multirow{2}{*}{$\begin{array}{l}\text { Thesis } \\
3.5 \%\end{array}$} & \multicolumn{2}{|c|}{ Total } \\
\hline & 8 & $4.3 \%$ & 4 & $3.7 \%$ & & & 25 & $17.5 \%$ & & 28 & $11.1 \%$ \\
\hline Applied Physics & 10 & $5.3 \%$ & 6 & $5.6 \%$ & 2 & $8.7 \%$ & 19 & $13.3 \%$ & $44.7 \%$ & 25 & $9.9 \%$ \\
\hline Computational \&Artificial Intelligence Sc. & 5 & $2.7 \%$ & 3 & $2.8 \%$ & & & 22 & $15.4 \%$ & $22.4 \%$ & 24 & $9.7 \%$ \\
\hline Atomic, Molecular \& Nuclear Physics & 2 & $1.1 \%$ & 2 & $1.9 \%$ & & & 16 & $11.2 \%$ & $22.4 \%$ & 18 & $7.2 \%$ \\
\hline Electronics & 5 & $2.7 \%$ & 1 & $0.9 \%$ & 1 & $4.4 \%$ & 15 & $10.5 \%$ & $11.2 \%$ & 17 & $6.8 \%$ \\
\hline Earth, Astrology \& Astrophysics & 3 & $1.6 \%$ & 3 & $2.8 \%$ & & & 14 & $9.8 \%$ & $22.4 \%$ & 16 & $6.4 \%$ \\
\hline Inorganic Chemistry & 15 & $8.0 \%$ & 13 & $12.0 \%$ & & & 4 & $2.8 \%$ & $1214.1 \%$ & 16 & $6.4 \%$ \\
\hline Pharmacy \& Pharmaceutical Technology & 16 & $8.5 \%$ & 14 & $13.0 \%$ & 1 & $4.4 \%$ & 2 & $1.4 \%$ & $1315.3 \%$ & 16 & $6.4 \%$ \\
\hline Physical Chemistry & 16 & $8.6 \%$ & 12 & $11.1 \%$ & 1 & $4.4 \%$ & 2 & $1.4 \%$ & $1011.8 \%$ & 13 & $5.8 \%$ \\
\hline Chemical Analysis & 10 & $5.3 \%$ & 7 & $6.5 \%$ & & & 5 & $3.5 \%$ & $67.1 \%$ & 11 & $4.4 \%$ \\
\hline Statistics \& Operational Research & 20 & $1.1 \%$ & 7 & $6.5 \%$ & 2 & $8.7 \%$ & 4 & $2.8 \%$ & $55.9 \%$ & 11 & $4.4 \%$ \\
\hline Organic Chemistry & 8 & $4.3 \%$ & 6 & $5.6 \%$ & & & 2 & $1.4 \%$ & $67.1 \%$ & 8 & $3.2 \%$ \\
\hline Algebra & 5 & $2.7 \%$ & 4 & $3.7 \%$ & 2 & $8.7 \%$ & 4 & $2.8 \%$ & $11.2 \%$ & 7 & $2.8 \%$ \\
\hline Computer Language Systems & 11 & $5.9 \%$ & 3 & $2.8 \%$ & 6 & $26.1 \%$ & & & & 6 & $2.4 \%$ \\
\hline Mathematical Analysis & 4 & $2.1 \%$ & 3 & $2.8 \%$ & & & 4 & $2.8 \%$ & $22.4 \%$ & 6 & $2.4 \%$ \\
\hline Morphological Science & 8 & $4.3 \%$ & 5 & $4.6 \%$ & 1 & $4.4 \%$ & 1 & $0.7 \%$ & $44.7 \%$ & 6 & $2.4 \%$ \\
\hline Human Geography & 4 & $2.1 \%$ & 2 & $1.9 \%$ & 3 & $13.0 \%$ & & & $22.4 \%$ & 5 & $2.0 \%$ \\
\hline Applied Mathematics & 12 & $6.4 \%$ & 1 & $0.9 \%$ & & & 3 & $2.1 \%$ & $11.2 \%$ & 4 & $1.6 \%$ \\
\hline Edaphology \& Chemical Agriculture & 5 & $2.7 \%$ & 3 & $2.8 \%$ & & & & & $33.5 \%$ & 3 & $1.2 \%$ \\
\hline Regional Geographic Analysis & 1 & $0.5 \%$ & 1 & $0.9 \%$ & 2 & $8.7 \%$ & & & $11.2 \%$ & 3 & $1.2 \%$ \\
\hline Physical Geography & 2 & $1.1 \%$ & 2 & $1.9 \%$ & & & & & $22.4 \%$ & 2 & $0.8 \%$ \\
\hline Architectural Design & 1 & $0.5 \%$ & 1 & $0.9 \%$ & & & & & $11.2 \%$ & 1 & $0.4 \%$ \\
\hline Architectural Graphic Expression & 3 & $1.6 \%$ & 1 & $0.9 \%$ & 1 & $4.4 \%$ & & & & 1 & $0.4 \%$ \\
\hline Crystalography \& Minerology & 1 & $0.5 \%$ & 1 & $0.9 \%$ & 1 & $4.4 \%$ & & & & 1 & $0.4 \%$ \\
\hline Geodynamics & 2 & $1.1 \%$ & 1 & $0.9 \%$ & & & 1 & $0.7 \%$ & & 1 & $0.4 \%$ \\
\hline Petrol \& Geochemistry & 1 & $0.5 \%$ & 1 & $0.9 \%$ & & & & & $11.2 \%$ & 1 & $0.4 \%$ \\
\hline Science Logic \& Philosophy & 1 & $0.5 \%$ & 1 & $0.9 \%$ & & & & & $11.2 \%$ & 1 & $0.4 \%$ \\
\hline Electrical Engineering & 1 & $0.5 \%$ & & & & & & & & & \\
\hline Engineering Graphic Expression & 2 & $1.1 \%$ & & & & & & & & & \\
\hline Geometry \& Topology & 1 & $0.5 \%$ & & & & & & & & & \\
\hline Opthalmic Optics & 2 & $1.1 \%$ & & & & & & & & & \\
\hline Theoretical Physics & 1 & $0.5 \%$ & & & & & & & & & \\
\hline Vegetable Production & 1 & $0.5 \%$ & & & & & & & & & \\
\hline Total & 187 & $100.0 \%$ & 108 & $100.0 \%$ & 23 & $100.0 \%$ & 143 & $100.0 \%$ & $85100.0 \%$ & 251 & $100.0 \%$ \\
\hline
\end{tabular}

Output of monographs during the 1975-1990 period grows considerably after 1980, reaching its highest plateau in 1987 with 38 books and 37 in 1990. As for the annual rate for books per female teacher, it can be seen that generally speaking the increase in the number of female teachers does not provide an immediate increase in the number of monographs, since it seems these teachers need a certain amount of time to publish, and the expected effect is not seen until following years, therefore, a differed effect is produced (Figure 2).

The change in the number of monographs in the three broad discipline areas along the $1975-1990$ period is seen to increase as female teachers starting years before begin to publish. The amount of these monographic publications is much higher in HSS, both because it is in this area where most monographs are published and also because it is the area with the greatest increase in female teachers compared to ST and MLS areas. 
A. M. MuÑOZ-MuÑOZ: Female academics at the University of Granada

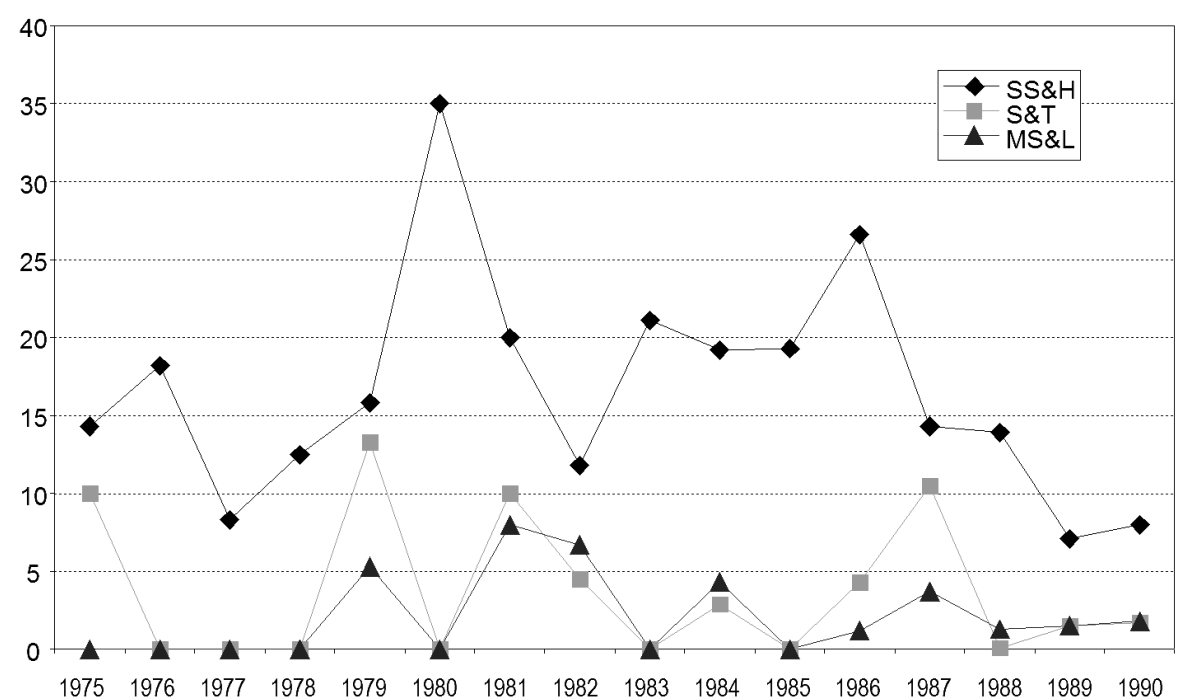

Figure 2. Annual monograph rate by broad discipline areas

Table 5. Publications. Female teachers and authors distribution in Medical and Life Sciences

\begin{tabular}{|c|c|c|c|c|c|c|c|c|c|c|c|c|}
\hline \multirow{2}{*}{$\begin{array}{l}\text { Discipline Areas in MS\&L } \\
\text { Microbiology }\end{array}$} & \multicolumn{2}{|c|}{ Fem. Teach. } & \multicolumn{2}{|c|}{ Fem. Author } & \multicolumn{2}{|c|}{ Books } & \multicolumn{2}{|c|}{ Articles } & \multicolumn{2}{|c|}{ Thesis } & \multicolumn{2}{|c|}{ Total } \\
\hline & 21 & $9.3 \%$ & 21 & $13.8 \%$ & & & 88 & $24.5 \%$ & 19 & $14.4 \%$ & 107 & $20.8 \%$ \\
\hline Medicine & 12 & $5.3 \%$ & 11 & $7.2 \%$ & & & 51 & $14.2 \%$ & 10 & $7.6 \%$ & 61 & $11.9 \%$ \\
\hline Pharmacology & 12 & $5.3 \%$ & 12 & $7.9 \%$ & 3 & $13.6 \%$ & 35 & $9.7 \%$ & 8 & $6.1 \%$ & 46 & $9.0 \%$ \\
\hline Physiology & 12 & $5.3 \%$ & 8 & $5.3 \%$ & 3 & $13.6 \%$ & 37 & $10.3 \%$ & 5 & $3.8 \%$ & 45 & $8.8 \%$ \\
\hline Parasitology & 9 & $4,0 \%$ & 5 & $3.3 \%$ & & & 36 & $10.0 \%$ & 4 & $3.0 \%$ & 40 & $7.8 \%$ \\
\hline Genetics & 4 & $1.8 \%$ & 3 & $2.0 \%$ & 1 & $4.5 \%$ & 33 & $9.2 \%$ & 3 & $2.3 \%$ & 37 & $7.2 \%$ \\
\hline Vegetable Biology & 15 & $6.7 \%$ & 8 & $5.3 \%$ & 6 & $27.3 \%$ & 23 & $6.4 \%$ & 7 & $5.3 \%$ & 36 & $7.0 \%$ \\
\hline Science History & 2 & $0.9 \%$ & 2 & $1.3 \%$ & 4 & $18.2 \%$ & 13 & $3.6 \%$ & 2 & $1.5 \%$ & 19 & $3.7 \%$ \\
\hline Paleontology & 3 & $1.3 \%$ & 3 & $2.0 \%$ & 1 & $4.5 \%$ & 13 & $3.6 \%$ & 2 & $1.5 \%$ & 16 & $3.1 \%$ \\
\hline Stomatology & 34 & $15.1 \%$ & 13 & $8.5 \%$ & & & 4 & $1.1 \%$ & 12 & $9.1 \%$ & 16 & $3.1 \%$ \\
\hline Biochemistry \& Molecular Biology & 17 & $7.6 \%$ & 11 & $7.2 \%$ & & & 3 & $0.8 \%$ & 10 & $7.6 \%$ & 13 & $2.5 \%$ \\
\hline Nutrition \& Bromatology & 11 & $4.9 \%$ & 7 & $4.6 \%$ & & & 4 & $1.1 \%$ & 6 & $4.5 \%$ & 10 & $1.9 \%$ \\
\hline Pathological Anatomy & 3 & $1.3 \%$ & 3 & $2.0 \%$ & 1 & $4.5 \%$ & 6 & $1.7 \%$ & 3 & $2.3 \%$ & 10 & $1.9 \%$ \\
\hline Cellular Biology & 10 & $4.4 \%$ & 8 & $5.3 \%$ & & & 1 & $0.3 \%$ & 8 & $6.1 \%$ & 9 & $1.7 \%$ \\
\hline Obstetrics \& Ginecology & 6 & $2.7 \%$ & 6 & $3.9 \%$ & & & 3 & $0.8 \%$ & 6 & $4.5 \%$ & 9 & $1.7 \%$ \\
\hline Nursing & 24 & $10.7 \%$ & 6 & $3.9 \%$ & 2 & $9.1 \%$ & 2 & $0.6 \%$ & 4 & $3.0 \%$ & 8 & $1.5 \%$ \\
\hline Animal Biology & 5 & $2.2 \%$ & 5 & $3.3 \%$ & & & 1 & $0.3 \%$ & 5 & $3.8 \%$ & 6 & $1.2 \%$ \\
\hline Pediatrics & 6 & $2.7 \%$ & 5 & $3.3 \%$ & 1 & $4.5 \%$ & & & 5 & $3.8 \%$ & 6 & $1.2 \%$ \\
\hline Preventive Medicine \& Public Health & 4 & $1.8 \%$ & 4 & $2.6 \%$ & & & 1 & $0.3 \%$ & 4 & $3.0 \%$ & 5 & $0.9 \%$ \\
\hline Toxicology \& Health Legislation & 2 & $0.9 \%$ & 2 & $1.3 \%$ & & & 4 & $1.1 \%$ & 1 & $0.8 \%$ & 5 & $0.9 \%$ \\
\hline Surgery & 7 & $3.1 \%$ & 4 & $2.6 \%$ & & & & & 4 & $3.0 \%$ & 4 & $0.8 \%$ \\
\hline Psychiatry & 3 & $1.3 \%$ & 2 & $1.3 \%$ & & & & & 2 & $1.5 \%$ & 2 & $0.4 \%$ \\
\hline Ecology & 1 & $0.4 \%$ & 1 & $0.6 \%$ & & & & & 1 & $0.8 \%$ & 1 & $0.2 \%$ \\
\hline Immunology & 1 & $0.4 \%$ & 1 & $0.6 \%$ & & & 1 & $0.3 \%$ & & & 1 & $0.2 \%$ \\
\hline Radiology \& Medicine & 1 & $0.4 \%$ & 1 & $0.6 \%$ & & & & & 1 & $0.8 \%$ & 1 & $0.2 \%$ \\
\hline Total & 225 & $100.0 \%$ & 152 & $100.0 \%$ & 22 & $100.0 \%$ & 359 & $100.0 \%$ & 132 & $100.0 \%$ & 513 & $100.0 \%$ \\
\hline
\end{tabular}


A. M. MuÑOZ-MuÑOZ: Female academics at the University of Granada

Table 6. Monograph authorship index

\begin{tabular}{lcccccc}
\hline $\begin{array}{c}\text { Broad } \\
\text { discipline } \\
\text { area }\end{array}$ & $\begin{array}{c}\text { Women } \\
\text { teachers }\end{array}$ & $\begin{array}{c}\text { Women } \\
\text { authors }\end{array}$ & Books & $\begin{array}{c}\text { Authorship } \\
\text { index }\end{array}$ & $\begin{array}{c}\text { Teachers } \\
\text { productivity } \\
\text { index }\end{array}$ & $\begin{array}{c}\text { Authors } \\
\text { productivity } \\
\text { index }\end{array}$ \\
\hline HSS & $300^{\mathrm{c}}$ & 108 & $210^{\mathrm{d}}$ & 0.36 & 0.70 & 1.94 \\
ST & 100 & 16 & 23 & 0.16 & 0.23 & 1.44 \\
MSL & 80 & 18 & 22 & 0.22 & 0.27 & 0.53 \\
\hline Total & 480 & $141^{\mathrm{e}}$ & $253^{\mathrm{f}}$ & 0.29 & 1.22 \\
\hline
\end{tabular}

${ }^{a}$ Women teachers here means the total of female teachers within those areas publishing monographs.

${ }^{\mathrm{b}}$ Women authors are those teachers who have written, or who we have found to have, at least one publication.

c The total number of teachers in HSS (300) does not coincide with the total of teachers from the dif ferent areas in which monographs are published (302) because two teachers change area (from Medieval History to History Science and Techniques, and from German Studies to English Studies). Therefore, it is appropriate to consider it within each area, but not in the total, otherwise the error of double counting would occur. $\mathrm{d}$ The number of monographs in HSS (210) does not correspond with the total of monographs from the different areas (214) in table 2 because three of them are co-written: the first monograph, written by two authors, one from the Teaching Methodology and School Management field and the other from Spanish Studies; the second, by four authors from Latin Studies, Spanish Studies, Arabic and Islamic Studies and History of Science (the latter belonging to MLS); the third by two authors, one from Latin Studies and the other from Ancient History. Therefore, it is appropriate to count them as one monograph within each area, but not in the total, otherwise double counting would occur.

e The total number of authors, (141), does not coincide with the total of authors by each area, (142), because there is a teacher from Human Sciences who published two monographs, each one within two different areas. For this reason she is considered as an author in each field of knowledge she publishes in, but not in the total of authors, as this would result in double counting.

${ }^{\mathrm{f}}$ The total number of monographs (253), does not coincide with the total of monographs from the three broad areas (255) because two of them are co-written: the first by two authors, one from Theory and History of Education, belonging to HS and the other from History of Science belonging to MLS; and the second, by four authors belonging to Latin Studies, Arabic Studies, Spanish Studies and History of Science (the first three belong to HS and the last to MLS). Therefore, it is appropriate to count them as one monograph within each broad area, but not in the total, so as to avoid double counting.

The presence of creative female authors is very significant, two out of every three female teachers are authors and one in every three is a co-author. On the other hand, the presence of non-creative authors, which is almost half of this group of women teachers, is compiler-editors (Table 7).

The diffusion of their monographic publications is mainly spread by university editorial entities (48.2\%) and commercial editorials (21.7\%) throughout Spain, concentrated in Granada (64.4\%) and Madrid (17.7\%). Outside of Spain diffusion is not significant, in fact only one book is published. 
A. M. MuÑOZ-MuÑOZ: Female academics at the University of Granada

\begin{tabular}{llrr} 
Table 7. Work associated with creative and non-creative female authors categories \\
\hline \multicolumn{1}{c}{ Roles } & Books & \multicolumn{1}{c}{$\%$} \\
\hline & Fem.authors & 135 & $67.8 \%$ \\
Creative fem. authors & Fem. co-authors & 58 & $29.2 \%$ \\
& Fem.collaborators.coordinators & 6 & $3.0 \%$ \\
& Total & 199 & $100.0 \%$ \\
& & & \\
& Fem. editors compilers & 26 & $48.1 \%$ \\
& Fem. directors-coordinators & 5 & $9.3 \%$ \\
& Fem. translators & 12 & $22.2 \%$ \\
& Fem. prologue writers & 9 & $16.7 \%$ \\
Fon-creative fem.athors & 2 & $3.7 \%$ \\
& Fem. Festschrift honoree & 54 & $100.0 \%$ \\
\hline
\end{tabular}

\section{Scholarly journal articles}

A total of 852 scholarly journal articles spread across $59 \%$ of areas, the highest level of output corresponding to the field of Microbiology with 88 articles, followed by Medicine with 51 and then Arabic and Islamic Studies with 46. The study of scholarly journal articles distribution throughout the discipline areas shows that it is amongst the areas belonging to HSS (42.6\%) and MLS (41\%) that $83.6 \%$ of total output is found, whilst ST only contributes $16.4 \%$ of that total. If in the case of monographic output the bulk of its production is contributed from the areas belonging to HSS areas, then where scholarly journal articles are concerned contribution is more divided out, since HSS and MLS provide almost the same amount of output and the difference with respect to that provided by ST is not as great as in the case of monograph output (see Tables 3, 4 and 5).

Of the 446 female authors during the study period, 196 of them have an article published in scholarly journals. The article frequency and female authors distribution shows us that more than half of the latter, $53.5 \%$, write between one and two scholarly articles throughout this period.

The authorship index shows us that approximately one in three female authors have published at least one article. Total output in areas with articles for the whole period reaches an approximate average of four articles for every three female teachers. However, if only the female authors are taken into account, the total productivity index of female authors during the whole period rises to more than four articles per female author. Output and productivity of scholarly journals articles is quantitively greater than that of monographs, because if quality is considered then it is supposed that the effort and work female teachers dedicate to the production of a book is greater than that dedicated to an article. If the three broad discipline areas are compared, HSS is the area 
that comprises most areas producing articles, and also where there are most female teachers, their authorship index being the highest and producing most scholarly journal articles. On the other hand, MLS, despite having fewer areas and female authors, reaches an amount of article output that is very close to that of female teachers in HSS. This is made possible due to the high productivity index of female MLS teachers, about six articles each, compared to fewer than four articles for female authors in HSS. Although the amount of output in ST is less than half than that produced in either of the other two broad discipline areas, its contribution is nevertheless significant, despite comprising fewer areas and also having fewer female authors producing articles, its productivity index is an average of seven articles for every two female authors (Table 8).

Output for scholarly journal articles during the 1975-1990 period is approximately $30 \%$ more than for that of monographs. It experiences considerable annual growth, in the same way as with monographs, from four articles published in 1975 to 145 in 1990. This last results heralds a new era, the nineties decade, with greater integration of female teachers into all aspects of the University and due to this providing greater contribution in all aspects where the number of articles published in scholarly journals could be no less. A deferred effect is also experienced in the scholarly journals just as in the monographs, although of a shorter duration. However, as a more regular pattern, it can be generally observed that an increase in the number of female teachers translates into a simultaneous increase in the number of articles published (Figure 3).

The changes in the number of articles published in scholarly journals in the three broad discipline areas during the 1975-1990 period show that HSS and MLS are those producing most, having a similar number of articles, less in ST. Looking closely at the changes it can be seen that within the areas belonging to HSS and MLS, contributions during the period are alternating, both of them closing the period with a huge increase and having by chance the same number of articles for 1990. On the other hand, the changes in ST are gradual and continuous. In the joint evolution of the annual number of articles in the broad discipline areas and the annual number of female teachers, during the years seeing an increase in the number of female teachers in HSS and MLS the number of published articles decreases. Although the number of women teachers increases in a gradual and more moderate fashion in MLS than in HSS, the first area publishes a larger number of articles. To the contrary, the increase in female teachers and published articles in ST is less but steady. Therefore, it can be said that women teachers coming into the University of Granada do not publish until years later, this time lapsus being less in the case of scholarly journal articles than in the monographic ones. 
Out of the total number of scholarly journal articles, a third of the University of Granada's women teachers have researched on their own and in two thirds of the articles have worked in a team, that is, works signed in co-authorship whose composition is mainly mixed (89.4\%); usually made up of two, three and four male/female authors.

Table 8. Article authorship index

\begin{tabular}{lcccccc}
\hline $\begin{array}{c}\text { Broad } \\
\text { discipline } \\
\text { area }\end{array}$ & $\begin{array}{c}\text { Women } \\
\text { teachers }\end{array}$ & $\begin{array}{c}\text { Women } \\
\text { authors }\end{array}$ & Articles & $\begin{array}{c}\text { Authorship } \\
\text { index }\end{array}$ & $\begin{array}{c}\text { Teachers } \\
\text { productivity } \\
\text { index }\end{array}$ & $\begin{array}{c}\text { Authors } \\
\text { productivity } \\
\text { index }\end{array}$ \\
\hline HSS & $282^{\mathrm{c}}$ & 98 & $364^{\mathrm{d}}$ & 0.35 & 1.29 & 3.71 \\
ST & $147^{\mathrm{e}}$ & 40 & $140^{\mathrm{f}}$ & 0.27 & 0.95 & 3.50 \\
MSL & $205^{\mathrm{g}}$ & 58 & $351^{\mathrm{h}}$ & 0.28 & 1.71 & 6.05 \\
Total & 634 & 196 & 855 & 0.31 & 1.34 & 4.35 \\
\hline
\end{tabular}

${ }^{a}$ Women teachers here means the total of teachers from those areas where articles from scientific publications are published.

${ }^{\mathrm{b}}$ Women authors are those teachers who have written, or who we have found to have, at least one publication. ${ }^{c}$ The total number of teachers from HSS (282) does not coincide with the total of teachers from the different areas in which articles are published (285), because there are three teachers who change area (from Medieval History to History Science and Techniques, from German Studies to English Studies and from Translation and Interpreting Applied Linguistics to German Studies. Therefore it is appropriate to consider them within each area, but not in the total, so as to avoid double counting.

${ }^{d}$ The total number of articles in HHS (364), does not coincide with the total of articles in the different areas (371) in Table 2 because seven of the articles are co-written: five of them written by two authors from the areas of Translation Applied Linguistics and English Studies respectively; another article by one author from Developmental Psychology and another from Personality and Evaluation of Psychological Treatment; and another by one author from Theory and History of Education and another from Ancient History. Therefore, it is appropriate to count them as articles within each area, but not in the total so as to avoid double counting.

${ }^{\mathrm{e}}$ The number of teachers in ST (147), does not coincide with the total of teachers from the different areas in which articles are published (149) because two of the teachers change area (from Pharmacy and Pharmaceutical Technology to Organic Chemistry, and from Applied Physics to Earth Physics, Astronomy and Astrophysics. Therefore it is appropriate to consider them within each area but not in the total so as to avoid double counting.

${ }^{\mathrm{f}}$ The total number of articles in ST (140) does not coincide with the total of articles in the different areas (143) in Table 3 because three of the articles are co-written by two authors: the first by one from the area of Electronics and another from Applied Physics; the second, belonging to Applied Physics and Earth Physics, Astronomy and Astrophysics; and the third by an author from Analytical Chemistry and one from Physical Chemistry. Therefore it is appropriate to count them as one article within each area, but not in the total so as not to double count.

$\mathrm{g}$ The number of teachers in MLS (205) does not coincide with the total of teachers in the different areas in which articles are published (207) because there are two who change area (from Physiology to Nursing and from Microbiology to Immunology). Therefore it is appropriate to consider them within each area but not in the total so as not to double count.

$\mathrm{h}$ The total number of articles in MLS (351), does not coincide with the total of articles in the different articles (359) in Table 4 because eight articles are co-written, four of them written by two authors from Medicine and from Toxicology and Health Legislation respectively; two articles by one author from Nursing and another from Microbiology respectively; an article written by an author from Pathological Anatomy and another from Parasitology. Therefore it is appropriate to count them as articles within each area, but not in the total so as not to double count. 
A. M. MuÑOZ-MuÑOZ: Female academics at the University of Granada

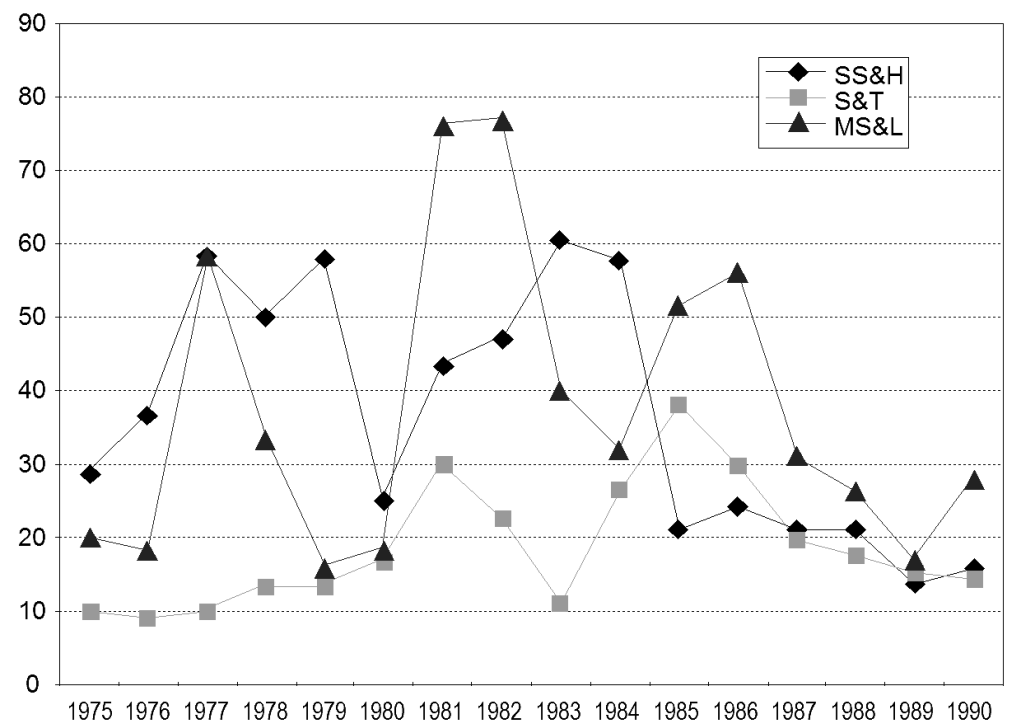

Figure 3. Annual article index by broad discipline areas

Women teachers usually taking part in these teams tend to sign first when the team has few members. In the case of articles signed by groups exclusively made up of women then the usual case is that they consist of two women (Table 9).

Table 9. Jointly-signed articles

\begin{tabular}{lrr}
\hline \multicolumn{1}{c}{ Roles } & Articles & \multicolumn{1}{c}{$\%$} \\
\hline Female authors & 281 & $33.0 \%$ \\
Fem. translators & 6 & $0.7 \%$ \\
\hline Fem.co-authors & 561 & $65.8 \%$ \\
Fem.co-translators & 4 & $0.5 \%$ \\
\hline Total & 852 & $100.0 \%$ \\
\hline
\end{tabular}

\begin{tabular}{|lcr|}
\hline & Joint Articles & $\%$ \\
\hline Female teams & 14 & $2.5 \%$ \\
Mixed teams & 505 & $89.4 \%$ \\
Not specified & 46 & $8.1 \%$ \\
\hline Total & 565 & $100.0 \%$ \\
\hline
\end{tabular}


The changes in the number of signatures per article during the study period have also been significant. The percentage of articles signed by a single female author decreases gradually and in the same approximate measure the percentage of articles signed by more than three male/female authors increases. At the beginning of the period, co-authored articles represented a little more than half and at the end almost $70 \%$, contrasted with $31.2 \%$ of articles signed by a single female author. However, this situation varies within the different discipline areas.

Despite co-authorship habits in the HSS areas increasing, they remain in low percentages, because the majority of articles during the years 1987-1990 are signed by a single female teacher. To the contrary, in ST and MLS areas, the percentage of coauthored articles is clearly higher than that of articles written by a single female author during the whole period. It can be stated that women authors of scholarly journal articles in HSS prefer to work on their own, whereas in ST and MLS trends to work in teams and publish in co-authorship are far more extended since the beginning (Figure 4).

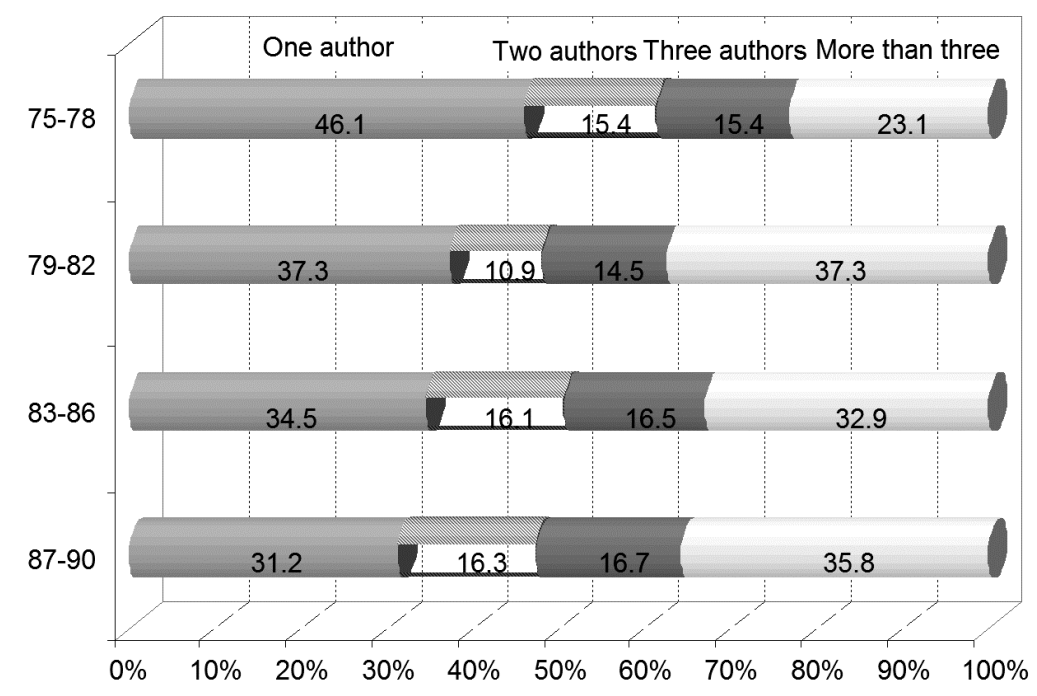

Figure 4. Articles signed by number of female authors

The majority of scholarly articles are disseminated through scholarly journals (95.7\%), the rest through non-specialist magazines. Two thirds of article output is published in national journals, and one third appears in foreign journals. Article dissemination varies according to the discipline areas the women authors belong to, so 
that, in HSS, publishing is mainly at a national level, in MLS it is more or less equally national or internationally and in ST the greatest number of articles are published internationally. This is reflected in the number of national and international journals in which female teachers publish during the period; for example, in HSS this is the case in many national journals and in ST in many foreign ones. In the case of MLS, although production of articles in national and foreign journals is balanced, there are more foreign than national journals, which shows that articles published by female teachers from this discipline are scattered in more titles internationally and more concentrated in fewer titles nationally.

Out of all of the articles written by female teachers, $852,(24.8 \%)$ of them have published in 104 impact journals. Their distribution through discipline areas remains biased in the HSS areas, as it is not sufficiently represented in the Institute for Scientific Information (ISI) database. So, female teachers belonging to the HSS area publish 12 articles $(3.3 \%)$ distributed in 11 impact journals, those belonging to ST publish 81 articles (57.9\%) in 33 impact journals and those in MLS 119 articles (33.9\%) in 61 impact journals. It can be confirmed that the work of women teachers from ST and MLS has the greatest international repercussion.

\section{Doctoral theses}

A total of 334 doctoral theses have been defended in $75 \%$ of the existing discipline areas at the University of Granada. The areas in which most theses have been defended are Microbiology (19 theses), Pharmacy and Pharmaceutical Technology (13), Stomatalogy and Inorganic Chemistry (12 theses each). Theses distribution by discipline areas shows that in those areas belonging to MLS the highest amount were defended with $40 \%$, followed by areas belonging to HSS with $34.2 \%$ and those of ST with $25.8 \%$. The amount of output is quite a lot more balanced in comparison with the amount obtained in monographic publications and scholarly journal articles (see Tables 3,4 and 5).

Although half of the areas with female teachers defending theses belong to HSS, the distribution of the number of theses defended by women teachers in the broad discipline areas shows that the main area is that of MLS, where a greater number of women teachers defend them (59\%), followed by ST (53\%) and HSS (37\%). As a whole, of the total number of female teachers (687) belonging to discipline areas where almost half publish (48\%) they defend their theses during the 1975-1990 period.

A high percentage of these theses have been considered to be of interest for the researching community since $67.3 \%$ of the defended theses have been published.

Throughout the period studied, the average number of theses defended is about 20.6 per year. The highest number of theses were defended in the years between 1985 and 1987, key dates for promotion and stabilisation of teaching staff brought about with the 
introduction of the U.R.L. Out of the 813 female teachers being a part of the University of Granada between 1975 and 1990, 40.6\% of them became Doctors during the sixteen years covered in the study, the highest percentages of female Doctors being during the last years of the seventies. The majority of the theses $(92.4 \%)$ were defended at the University of Granada, the rest being shared out amongst eleven Spanish universities, this data indicating that these women teachers were students from the University of Granada itself (Figure 5).

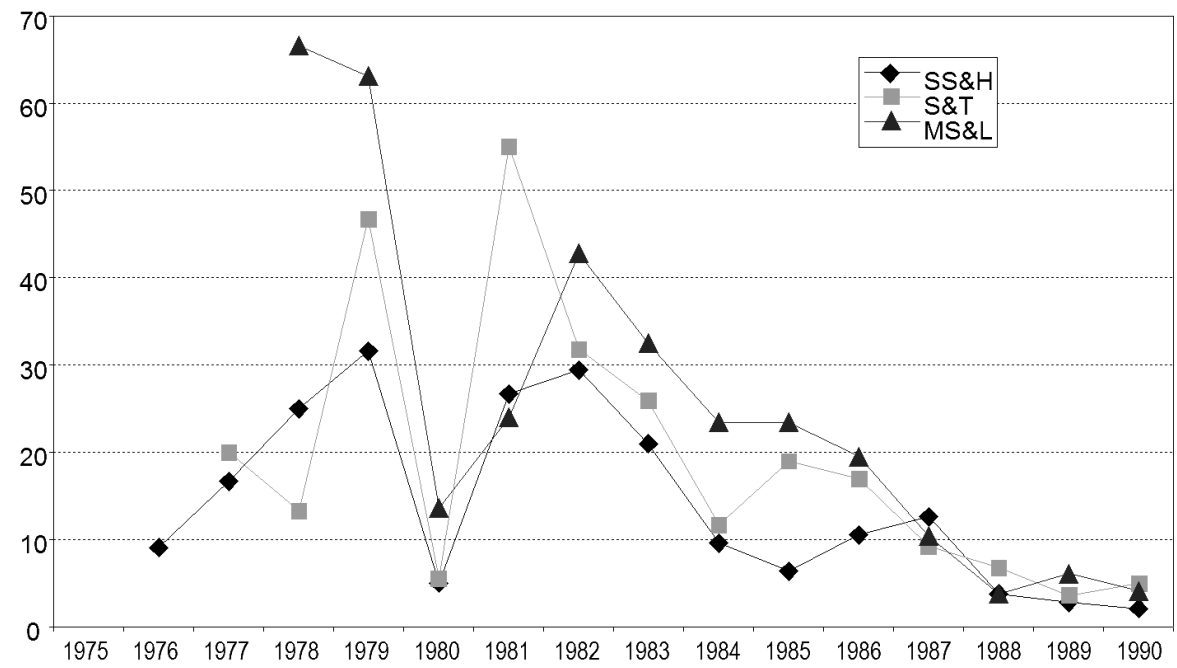

Figure 5. Annual rate of Doctoral theses by broad discipline areas

Table 10. Thesis supervision distribution by gender

\begin{tabular}{lrrrrrrrr}
\hline & \multicolumn{2}{c}{ Female } & \multicolumn{2}{c}{ Mixed } & \multicolumn{2}{c}{ Male } & \multicolumn{2}{c}{ Total } \\
\hline Thesis supervised & 9 & $3.2 \%$ & - & - & 192 & $68.3 \%$ & 201 & $71.5 \%$ \\
Thesis co-supervised & 3 & $1.1 \%$ & 18 & $6.4 \%$ & 59 & $21.0 \%$ & 80 & $28.5 \%$ \\
\hline Total & 12 & $4.3 \%$ & 18 & $6.4 \%$ & 251 & $89.3 \%$ & 281 & $100.0 \%$ \\
\hline
\end{tabular}

As far as the supervision of these theses was concerned, $89.3 \%$ were supervised or co-supervised by males and $4.3 \%$ by women, the rest by mixed co-supervision (Table 10). The percentage of women supervising or co-supervising theses is very low, since their overall representation in the University's staff is also lower, they therefore have fewer possibilities of being selected to supervise a thesis. It is representative that the number of co-supervised theses including women in their supervision is greater than 
the number of those supervised by a woman on her own, which indicates a clear tendency to work in groups. This inclination towards teamwork could be interpreted as a way of uniting strengths and creating power spaces where the female sex is represented with the prestige that the supervision of a thesis in the university sphere offers, versus the position of academic power that males exert by supervising a greater number of theses simply for being in the majority and therefore for being noticed more in the university community.

\section{Conclusions}

The means used by women teachers at the University of Granada during the 1975-1990 period to disseminate the results of their research are the following: first, scholarly journal articles occupying $59.4 \%$ of the total of publications analysed, doctoral theses come second with $23 \%$ and in third place, monographs which represent $17.6 \%$ of the total output.

During the 1975-1990 period female teachers' research activity at the University of Granada goes through some changes, reflected in a constant increase in the number of women teachers and authors, this being an almost parallel increase to the number of publications and therefore the number of women teachers publishing their works, especially standing out the considerable growth of the final five years of the study period. Moreover, if the scholarly output of the same women teachers is considered during the nine years following, 1991-1999, output is seen to increase by $68 \%$ (MUÑOZ, 2002).

This momentum in the increase of scholarly works is the result of participation and political struggle by men and women to achieve a democratic state also reflected in Spanish universities, of the Spanish Constitution of 1978 which contemplates equality of rights for men and women, of womens' access to the world of education and culture and of women joining the work force. The striving for better scholarly and technological policy on the part of political representatives during democracy cannot be forgotten either, nor, of course, the individual and common desire on the part of all these women for their work to be recognised in the academic and scholarly world.

Although a stalemate has been reached in the equity between male and female teaching staff in the overall group, the changes for female teachers at the University of Granada, for the 1975-1990 period, have been positive if the statistics showing the increase in female staff are considered, and negative if the ratio male/female teachers is considered. This growth which has been constant can be seen in the accession of women teachers into new discipline areas where only men worked before. With the introduction of the URL both the male and female staff benefited from work stability, but since this Reform Law a minority of women teachers have reached the highest academic category, that of full professor with a Ph.D. At present this situation is made 
worse against female teachers since the new University Law (U.L.) ${ }^{8}$ allows $51 \%$ of the staff to be tenured, if it is taken into account that on average Spanish universities have at present $60 \%$ tenured teaching staff, then it is very difficult to achieve power equity in the Spanish university system.

Women teachers' scholarly output by broad discipline areas is proportional to the number of women teachers and authors that belong to the area. Female teachers belonging to the HSS areas publish $47.7 \%$ of total output, followed by MLS with $35.1 \%$ and ST with $17.2 \%$. In this case it can be said that women teachers belonging to "traditionally female" discipline areas are those that disseminate the most number of publications. On the other hand, areas belonging to HSS and ST are the areas with the highest percentages of publications, $54.3 \%$ and $26 \%$, respectively, and MLS with $19.7 \%$.

The scholarly output analysed here is mainly disseminated in the national context, $74.4 \%$ of total output, without including doctoral theses since these are initially published nationally and $26.6 \%$ are disseminated abroad. The Monograph is the most used typology for national dissemination, $99.6 \%$ of all monographs. As far as article dissemination is concerned, $24.4 \%$ of their total is published in impact journals distributed between 7 national ones and 97 foreign ones.

In jointly signed publications, the make up of the group is dominantly mixed. Out of these work teams, including those articles signed in alphabetical order, more than half of the female teachers sign in first position, $57.4 \%$, this reflecting equal participation and recognition in the research groups developed by team groups of men and women.

Changes occurring during the Spanish political Transition set the foundations for more women to join research activity. It also provides the groundwork for quality participation, but not to centres of power and decision-making within the academic structure. Nevertheless, the increase in female teaching staff has triggered the creation of opportunities for exchanging knowledge amongst women and for agreements and pacts between them within the university context which is self-evident with the founding of The University Institute for Womens' Studies. The mere addition of women to the staff and, especially, to research activity, has provided a different way of questioning reality, or to the contrary it could mean accepting traditional male-centred values, just as much in roles carried out in academic structures as in research results.

\footnotetext{
${ }^{8}$ The University Law passed on the 24th December 2001 replaces the former law of University Reform.
} 


\section{References}

BORDONS, M., BARRIGÓN. S. (1992a), Bibliometric analysis of publications of Spanish pharmacologists in the SCI (1984-89). II. Contribution to subfields other than "Pharmacology \& Pharmacy" (ISI). Scientometrics, 25 (3) : 425-446.

Bordons, M., GARcíA-Jover, F., BARrigón, S. (1992b), Bibliometric analysis of publications of Spanish pharmacologists in the SCI (1984-89). I. Contribution to the "Pharmacology \& Pharmacy" subfield (ISI). Scientometrics, 24 (1) : 163-177.

Bordons, M., Morillo, F., Fernández, M. T., Gómez, I. (2003), One step further in the production of bibliometric indicators at the micro level: Differences by gender and professional category of scientists. Scientometrics, 57 (2) : 159-173.

Campanario, J. M., Cabos, W., Hidalgo, M. Á. (1998), El impacto de la producción científica de la Universidad de Alcalá de Henares. Revista Española De Documentación Científica, 21 (4) : 402-415.

Chakravarty, R., Chawla, A., Mehta, G. (1988), Women scientists at work - An international comparative study of six countries, Scientometrics, 14 (1-2) : 43-74.

CINDOC (2003). Indicadores bibliométricos por género. Desarrollo de una metodología y resultados iniciales de su aplicación en el área de Ciencia Agrarias del CSIC. Informe octubre 2003.

GLÄNZEL, W., SCHOEPFLIN, U. (1999), A bibliometric study of reference literature in the Sciences and Social Sciences, Information Processing \& Management, 35 (1) : 31-44.

JiMÉNEZ CONTRERAS, E. (1997), Universidad de Granada: 1975-1987. La transición cientifica: (Un estudio sobre la difusión internacional de la literatura científica granadina). Granada: Universidad.

LEMOINE, W. (1992), Productivity patterns of men and women scientists in Venezuela. Scientometrics, 24 (2) : 281-295.

MÉndeZ, A., SAlvador, P. (1992), The application of scientometric indicators to the Spanish scientific research council. Scientometrics, 24 (1): 61-78.

MuÑoz-MuÑoz, A. M. (2003), Producción cientifica de las profesoras en la Universidad de Granada durante los años 1975-1990. [Tesis doctoral]. Granada: Universidad.

Naldi, F., Vannini, I. (2002), Scientific and Technological Performance by Gender. A Feasibility Study on Patent and Bibliometric Indicators. European Commission; 2002. 2 vol.

PESTAÑA, Á. (1992), Spanish performance in Life Sciences. A comparative appraisal of the scientific production of Spain and five other European countries in 1989. Scientometrics, 24 (1) : 95-114.

PRICE, D. J. DE Solla (1973), Hacia una ciencia de la ciencia. Barcelona: Ariel. 